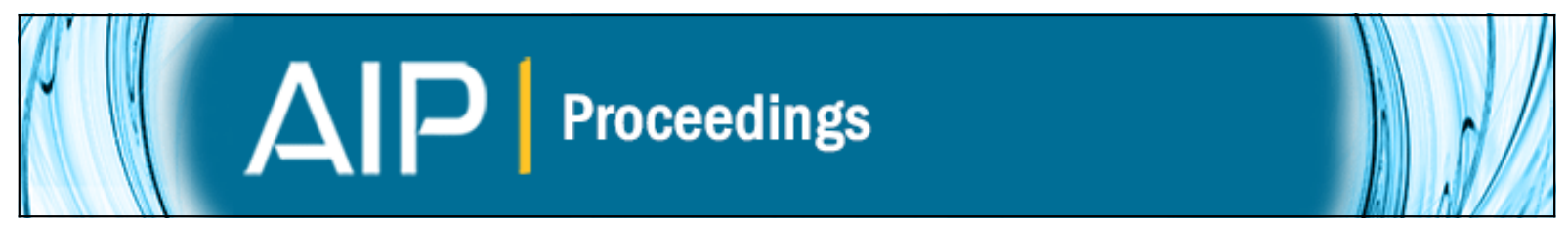

\title{
THE NEXUS OF ENERGY AND WATER IN THE UNITED STATES
}

\author{
MICHAEL E. WEBBER
}

Citation: AIP Conference Proceedings 1401, 84 (2011); doi: 10.1063/1.3653847

View online: http://dx.doi.org/10.1063/1.3653847

View Table of Contents: http://scitation.aip.org/content/aip/proceeding/aipcp/1401?ver=pdfcov

Published by the AIP Publishing

\section{Articles you may be interested in}

Renewable Electricity in the United States: The National Research Council Study and Recent Trends AIP Conf. Proc. 1401, 369 (2011); 10.1063/1.3653864

Science and Technology to Support a National Energy Strategy for the United States AIP Conf. Proc. 1044, 49 (2008); 10.1063/1.2993737

Infrared Technology Trends and Implications to Home and Building Energy Use Efficiency AIP Conf. Proc. 1044, 217 (2008); 10.1063/1.2993722

Technologies and Policies to Improve Energy Efficiency in Industry

AIP Conf. Proc. 1044, 163 (2008); 10.1063/1.2993718 


\title{
THE NEXUS OF ENERGY AND WATER IN THE UNITED STATES
}

\author{
MICHAEL E. WEBBER \\ Associate Director, Center for International Energy \& Environmental Policy \\ and Mechanical Engineering Department \\ University of Texas at Austin \\ Austin, Texas
}

\begin{abstract}
This manuscript presents an overview and a relevant framework for thinking about the nexus of energy and water. Here are the key points of this article:

- $\quad$ Energy and water are interrelated; we use energy for water and water for energy

- The Energy-water relationship is under strain, and that strain introduces cross-sectoral vulnerabilities (that is, a water constraint can become an energy constraint, and an energy constraint can induce a water constraint)

- Trends imply that this strain will be exacerbated because of 1) growth in total demand for energy and water, primarily driven by population growth, 2) growth in per capita demand for energy and water, primarily driven by economic growth, 3) global climate change, which will distort the availability of water, and 4) policy choices, by which we are selecting more waterintensive energy and more energy-intensive water
\end{abstract}

\section{INTRODUCTION}

Energy and water are both fundamental ingredients of modern civilization and are precious resources. They are key inputs to our agricultural systems, factories, and buildings, and it can be argued that they are even more fundamental than food, shelter, healthcare and education.

Energy and water are also closely interconnected and under strain. Consequently, the nexus of the two has been the subject of recent attention by the scientific community [3-5], popular media [1-2, 6-9], and Congress [10]. This nexus manifests itself in society in many ways. For example, water provides electric power and plays a growing role for irrigation of energy crops to produce biofuels such as ethanol. And, the thermoelectric sector is the largest user of water in the U.S., for cooling. In parallel, the water industry uses power for moving, pumping, treating, and heating water. On top of this relationship, the parts of the world with high-expected rates for population growth and economic expansion are also often places where water sources are scarce. Combining these trends with projections for more irrigation implies rapid growth for water demands that localities might satisfy with desalination or wastewater treatment, both of which are very energy-intensive.

Physics of Sustainable Energy II: Using Energy Efficiently and Producing it Renewably

AIP Conf. Proc. 1401, 84-106 (2011); doi: 10.1063/1.3653847

(C) 2011 American Institute of Physics 978-0-7354-0972-9/\$30.00 
Despite all these advances, approximately 2.4 billion people live in highly waterstressed areas. Furthermore, the largest public health problem globally remains the more 1.1 billion people without access to improved freshwater sources $[11,12]$ for drinking, cooking and washing (100 million people in China alone [13]), and 2.6 billion remain vulnerable to water-borne diseases because they lack access to wastewater treatment (e.g. sanitation). [11, 12] Consequently, it has been noted that improving water quality is a significant way to improve public health worldwide [1416]; however, creating universal access to clean water will require a lot of energy for treatment and moving it to where it is needed. Thus, it is fair to say that solving the world's public health crises begins at the nexus of energy and water.

Despite the importance of each and the close relationship of energy and water, the funding, policymaking, and oversight of these resources are typically performed by different people in separate agencies. Also, energy planners often assume they will have the water they need and water planners assume they will have the energy they need-if one of these assumptions fails, the consequences will be dramatic. By bringing scientific and engineering expertise to bear on this vastly understudied problem, this scenario might be avoided.

This manuscript brings some of the relevant information together to present an overview and a relevant framework for thinking about the nexus of energy and water. Here are the key points of this article:

- Energy and water are interrelated; we use energy for water and water for energy

- The Energy-water relationship is under strain, and that strain introduces crosssectoral vulnerabilities (that is, a water constraint can become an energy constraint, and an energy constraint can induce a water constraint)

- Trends imply that this strain will be exacerbated because of 1) growth in total demand for energy and water, primarily driven by population growth, 2) growth in per capita demand for energy and water, primarily driven by economic growth, 3) global climate change, which will distort the availability of water, and 4) policy choices, by which we are selecting more waterintensive energy and more energy-intensive water

This manuscript examines each of these points in detail and then closes with policy recommendations for how to mitigate the most vulnerable aspects of the energy-water nexus.

\section{Energy \& Water Are Interrelated}

In addition to these two resources being the most essential ingredients of modern civilization, they are also highly interconnected. That is, we use water for energy and energy for water. For example, water is a direct source of energy through hydroelectric dams, which provide about 7\% of total US electricity generation (268 million MWh in 2006), or approximately $3 \%$ of total energy consumption) in the US.[17] 
In addition to direct power generation, water indirectly enables power generation through the cooling it provides for thermoelectric power plants, which provide more than $90 \%$ of the electricity in the US (approximately 3,500 million MWh).[17] As a result of the large cooling needs for power plants, the thermoelectric power sector is the single largest user of water in the nation, responsible for nearly half of all water withdrawals (about 200 billion gallons per day, when including seawater), ahead of even agriculture.[19] When considering only freshwater withdrawals, then the power plants and agriculture are approximately tied for first place among users.

An important feature of water use is the distinction between water withdrawals and consumption. Nearly all of the water used for power plants is returned to the source (typically a river or cooling pond), though at a different temperature and quality. As a result of these returns, power plants are responsible for a small portion of national water consumption, despite being the leading sector for withdrawals. On average across the thermoelectric power sector, 21 gallons of water are withdrawn and 0.5 gallons consumed for every kilowatt-hour of electricity that is generated (please see Table 1).[20] Note that the hydroelectric sector is listed in Table 1 for comparison. Hydroelectric dams are associated with a significant amount of water consumption for power generation primarily because the increased surface area of man-made reservoirs beyond the nominal run-of-river accelerates the evaporation rates from river basins.[21] Notably, the estimates for this increased evaporation depend significantly on regional location. Furthermore, whether all the evaporation should be attributed to power generation is not clear, as reservoirs serve multiple purposes, including water storage, flood control, and recreation.

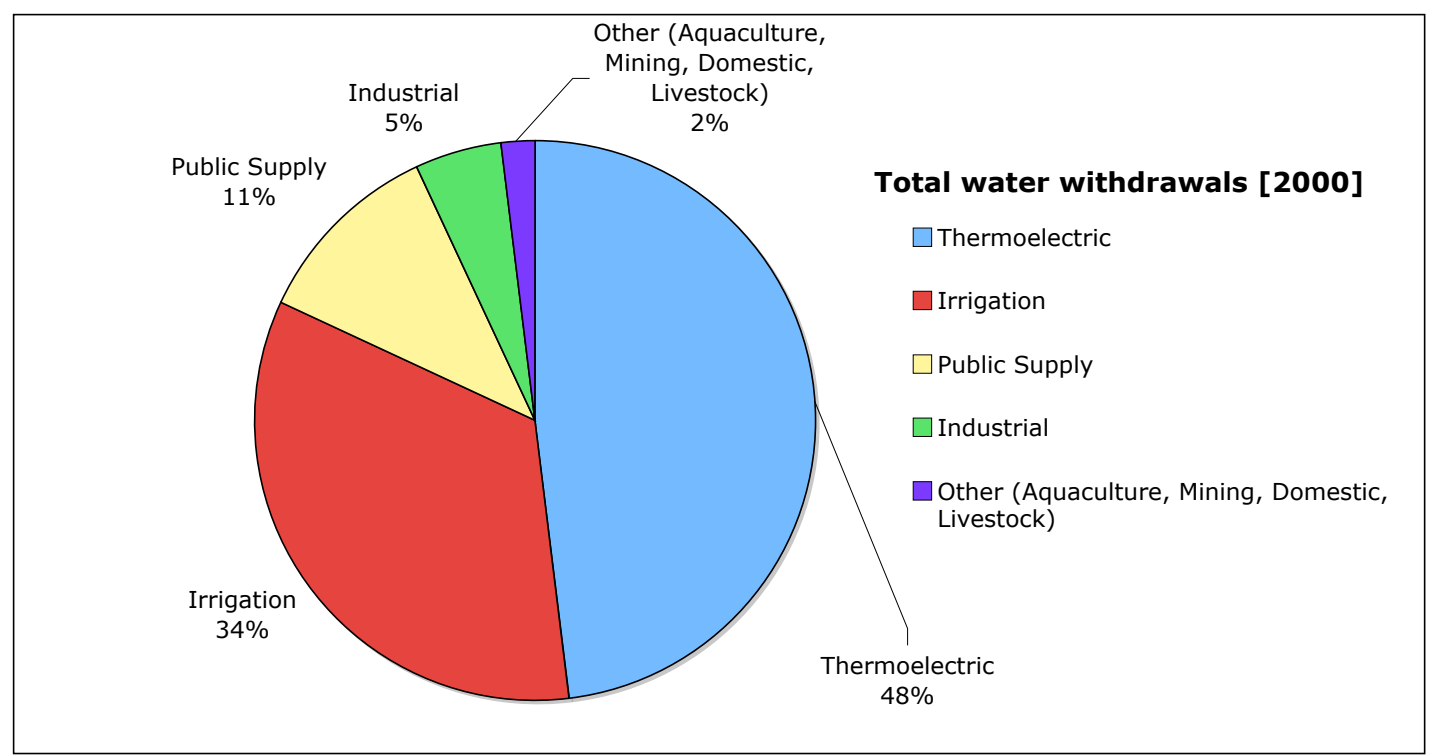

FIGURE 1. Total water withdrawals in the US by sector, including fresh and saline water.[19] 

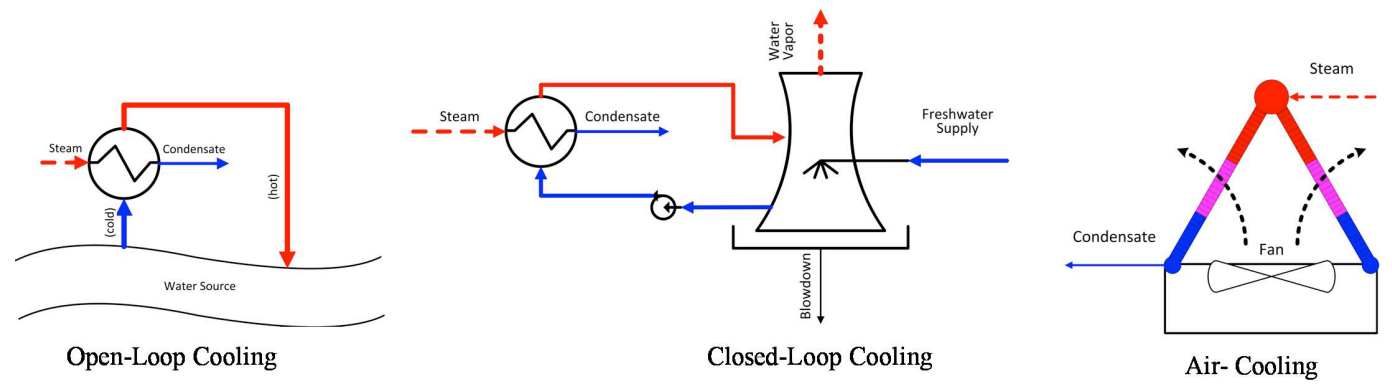

FIGURE 2. Power-plants typically use three types of cooling: open-loop, closed-loop and air cooling.[78]

The amount of water that is withdrawn and consumed by thermal power plants is driven primarily by 1) the type of fuel and power cycle that a power plant uses (for example fossil fuels or nuclear fuels with steam cycles, natural gas with combined cycle, etc.) and 2) the cooling method. There are three basic cooling methods: openloop, closed-loop, and air-cooling (see Figure 2).[22] For figures on water withdrawal and consumption by power plants, please see Table 1 for national averages and Table 2 for a breakdown by fuel and cooling type.

Open-loop, or once-through, cooling withdraws large volumes of surface water, fresh and saline, for one-time use and returns nearly all the water to the source with little of the overall water being consumed due to evaporation. While open-loop cooling is energy efficient and low in infrastructure and operational costs, the discharged water is warmer than ambient water, causing thermal pollution, which can kill fish and harm aquatic ecosystems. Thus, environmental agencies regulate discharge temperatures, taking into account a water body's heat dissipation capacity. Closed-loop cooling requires less water withdrawal, since the water is recirculated through use of cooling towers or evaporation ponds. However, since the cooling is essentially achieved through evaporation, closed-loop cooling results in higher water consumption (See Table 2). The alternative, air-cooling, does not require water, but instead cools by use of fans that move air over a radiator similar to that in automobiles. However, power plant efficiency for air-cooling is lower, up-front capital costs are higher, and real estate requirements are sometimes larger, often making this option less attractive economically unless water resources are scarce.

Even though power plants return most of the water they withdraw, the need for such large amounts of water at the right temperature for cooling introduces vulnerabilities for the power plants. If a severe drought or heat wave reduces the availability of water or restricts its effectiveness for cooling due to heat transfer inhibitions or thermal pollution limits, the fact that the power plant consumes so little water becomes less important than the fact that it needs the water in the first place. 
TABLE 1. The water used (withdrawn and/or consumed) for different types of power plants (thermal and hydro). The national average from thermo- and hydro-electric sources is that 2 gallons of water is consumed per $\mathrm{kWh}$ of electricity that is generated.[20]

\begin{tabular}{|l|c|c|}
\hline \multicolumn{1}{|c|}{ Power Source } & $\begin{array}{c}\text { Withdrawals } \\
\text { [gal/kWh] }\end{array}$ & $\begin{array}{c}\text { Consumption } \\
\text { [gal/kWh] }\end{array}$ \\
\hline Thermoelectric (National Average) & 21 & 0.5 \\
\hline Hydroelectric & 18 & 18 \\
\hline National Average (all types) & --- & 2 \\
\hline
\end{tabular}

Just as significant volumes of water are used for energy, a significant fraction of national energy is used for water. Specifically, to heat, treat and move water, sometimes across vast distances. For example, on the west coast, where snowmelt is moved across two mountain ranges to thirsty Southern Californians, a single aqueduct is the largest electricity customer in the state.[27, 28] The pithy maxim that "Water flows uphill towards wealth" reflects the amount of effort and money that is required to move water due to its density. In addition, hot water is needed for hygiene reasons such as showers, cooking and cleaning. Consequently, $9 \%$ of all residential electricity use is just for water heating alone,[29] which does not include the direct use of natural gas on-site in the residential or commercial sectors for water heating. The wastewater treatment and water sectors also consume vast amounts of energy, primarily in the form of electricity, for water supply and treatment.[17, 30] The old adage that "sewage flows downhill" partly reflects the reality of dense, solid-laden water streams flowing downward from mountaintop castles to the villages below is a nod towards the vast energy requirements that would be used to move wastewater the other direction.

TABLE 2. The water used (withdrawn and/or consumed) varies for different fuels (coal, nuclear, natural gas, solar and wind), power cycles (combined and open cycle), and cooling methods (open-loop, closed-loop and air-cooling).[78]

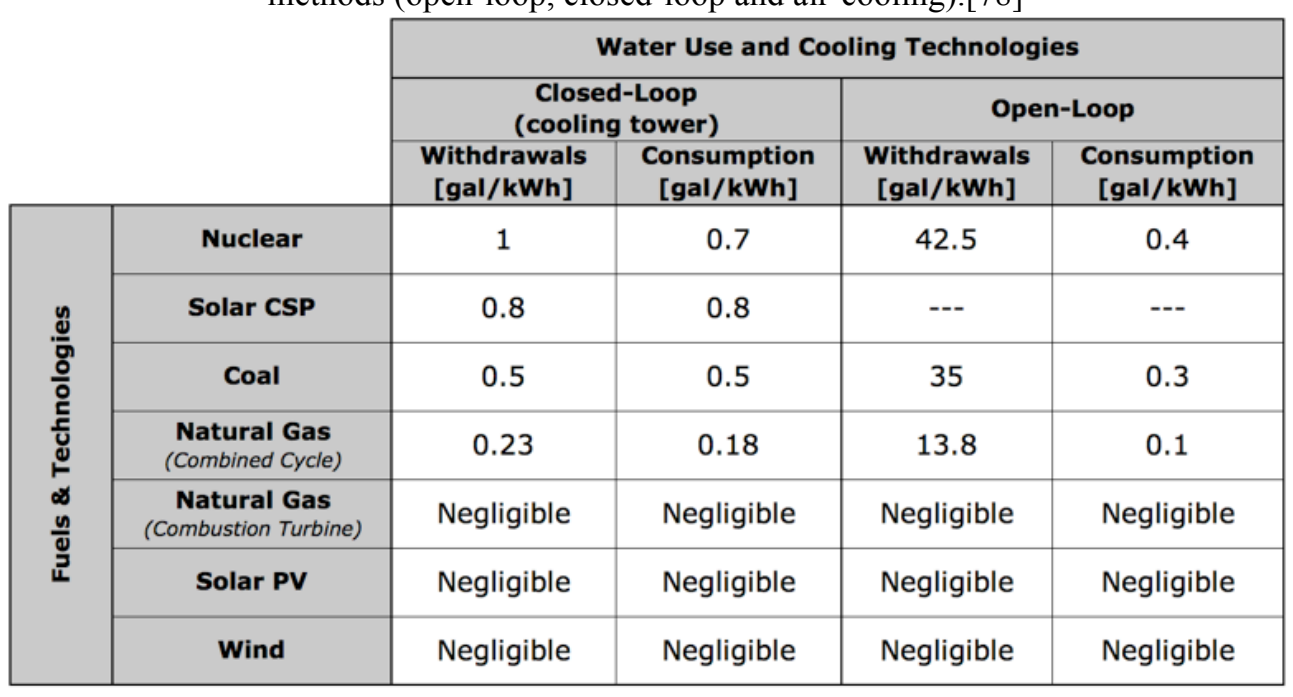

The energy required to produce, treat and distribute water varies depending on the source (see Table 3). Surface water (e.g. from lakes and rivers), is the easiest and least 
energy-intensive to treat. However, note that for states like California, water conveyance can require as little as $0 \mathrm{kWh}$ per million gallons (for gravity-fed systems) to as much as $14,000 \mathrm{kWh}$ per million gallons for long-haul systems.[27, 28] Groundwater (e.g. from aquifers) requires more energy, primarily for pumping water to the surface for treatment and distribution. For example, water collection alone from a depth of 120 feet requires $540 \mathrm{kWh} /$ million gallons, while a depth of 400 feet requires $2000 \mathrm{kWh} /$ million gallons, in addition to treatment energy use.[31, 32, 78]

As fresh water supplies become strained, many have turned to water sources once considered unusable, including brackish groundwater and seawater.[79] While use of these water sources helps mitigate constraints on drinking water supplies, treatment of brackish groundwater and seawater requires use of advanced filtration (e.g. reverse osmosis membranes), specialty materials, and high pressure pumps for desalting. Overall, treatment of these water sources can require as much as $16,500 \mathrm{kWh}$ per/Mgal,[31] or 10-12 times the energy use of standard water treatment. The theoretical minimum energy requirement for desalination using reverse osmosis systems is $2650 \mathrm{kWh} / \mathrm{Mgal} .[33]$

TABLE 3. Water and wastewater treatment and conveyance requires vast amounts of energy. Average US figures for water production are listed below, and include the energy use for distribution. [27, 30,31,78]

\begin{tabular}{|c|c|c|}
\hline Water Type & Source / Treatment Type & $\begin{array}{c}\text { Energy Use } \\
\mathbf{( k W h / m i l l i o n ~ g a l )}\end{array}$ \\
\hline \multirow{4}{*}{ Water } & Surface Water & 1,400 \\
\cline { 2 - 3 } & Groundwater & 1,800 \\
\cline { 2 - 3 } & Brackish Groundwater & $3,900-9,750$ \\
\cline { 2 - 3 } & Seawater & $9,780-16,500$ \\
\hline \multirow{4}{*}{ Wastewater } & Trickling Filter & 955 \\
\cline { 2 - 3 } & Activated Sludge & 1,300 \\
\cline { 2 - 3 } & Advanced Treatment without Nitrification & 1,500 \\
\cline { 2 - 3 } & Advanced Treatment with Nitrification & 1,900 \\
\hline
\end{tabular}

Wastewater treatment also requires large amounts of energy. Wastewater treatment in the US is primarily conducted by the over 16,000 Publicly Owned Treatment Works (POTWs).[34] POTWs are often the largest local consumer of energy, generally requiring 1 to $3 \%$ of a community's total energy use, and a non-negligible fraction of national energy consumption[17, 35]. Stricter discharge regulations in the United States led to implementation of more energy-intensive treatment technologies. Trickling filter treatment, which uses a biologically active substrate for aerobic treatment, is a reasonably passive system, consuming over $950 \mathrm{kWh} / \mathrm{Mgal}$ on average.[31, 78] Diffused air aeration as part of activated sludge processing is a more energy intensive form of wastewater treatment around, requiring 1,300 $\mathrm{kWh} / \mathrm{Mgal}$ due to blowers and gas transfer equipment. $[31,78]$ More advanced wastewater treatment, utilizing filtration and the option of nitrification, requires 1,500-1,900 kWh/Mgal.[31, 78] In fact, more advanced sludge treatment and processing can consume energy in the range of $30-80 \%$ of total wastewater plant energy use.[36] POTWs that treat wastewater sludge through anaerobic digestion can also produce energy through the 
creation of methane-rich biogas, a renewable fuel that can be used to generate up to $50 \%$ of the POTW's electricity needs[30,37].

Looking at just the public supply of water, which is primarily for the residential and commercial sectors, approximately $4.7 \%$ of the nation's annual primary energy and $6.1 \%$ of national electricity consumption, respectively, is required for water.[80] End-use energy requirements associated with water for municipal, industrial, and selfsupplied sectors (i.e. agriculture, thermoelectric, mining, etc.) represents another 5\% or more of national energy consumption.

\section{Globally the Energy-Water Relationship Is Already Under Strain}

The interrelationship of energy and water and the strains on both resources manifests itself in tough choices at the local level. For example, low water levels in hydroelectric reservoirs can force power plants to turn off. Fifty-eight percent of US hydroelectricity is generated in California, Oregon, and Washington alone, making the power supply vulnerable to regional changes in water availability. Though hydroelectric power is attractive for many reasons, it is least reliable during droughts when the need to use water for other purposes (e.g. for drinking, irrigation, etc.) may take precedence over hydroelectricity. For example, without a change in water usage patterns, Lakes Mead and Powell along the Colorado River, which are used for hydroelectric power and municipal supply, are projected to have a 50\% chance of running dry by 2021.[18] Outside Las Vegas, Lake Mead has dropped 100 feet in six years, making people worry whether the massive hydroelectric turbines inside Hoover Dam would no longer turn and the city would have to ration water use. ${ }^{52-54}$ Cities in Uruguay must choose whether they want the water in their reservoir to be used for drinking or electricity.[51]

The problem is not just limited to hydroelectric reservoirs. Since thermoelectric power plants also require vast amounts of water, they are vulnerable to droughts or heat waves restricting their output. Heat waves in France in 2003 also caused power plants to draw down their output because of limits on rejection temperatures that are imposed for environmental reasons. $[6,24,25]$ That severe heat wave and drought killed approximately 15,000 people and created river water levels that were too hot for effective power plant cooling. As a consequence, many nuclear power plants had to operate at much reduced capacity and an environmental exemption was enacted to allow the rejection temperatures of cooling water from power plants to exceed prior limits.[24, 25] At the same time, $20 \%$ of hydropower capacity was not available because of low river levels.[6] That is, just as demand for electricity was spiking for air conditioning in response to the heat, supplies were being cut back. The dilemma has also shown up in the United States. For example power plants in Atlanta during the winter 2008 drought were within daof shutting off because the vast amounts of cooling water were at risk from diversion for other priorities such as municipal use for drinking water.[23, 55, 56] 


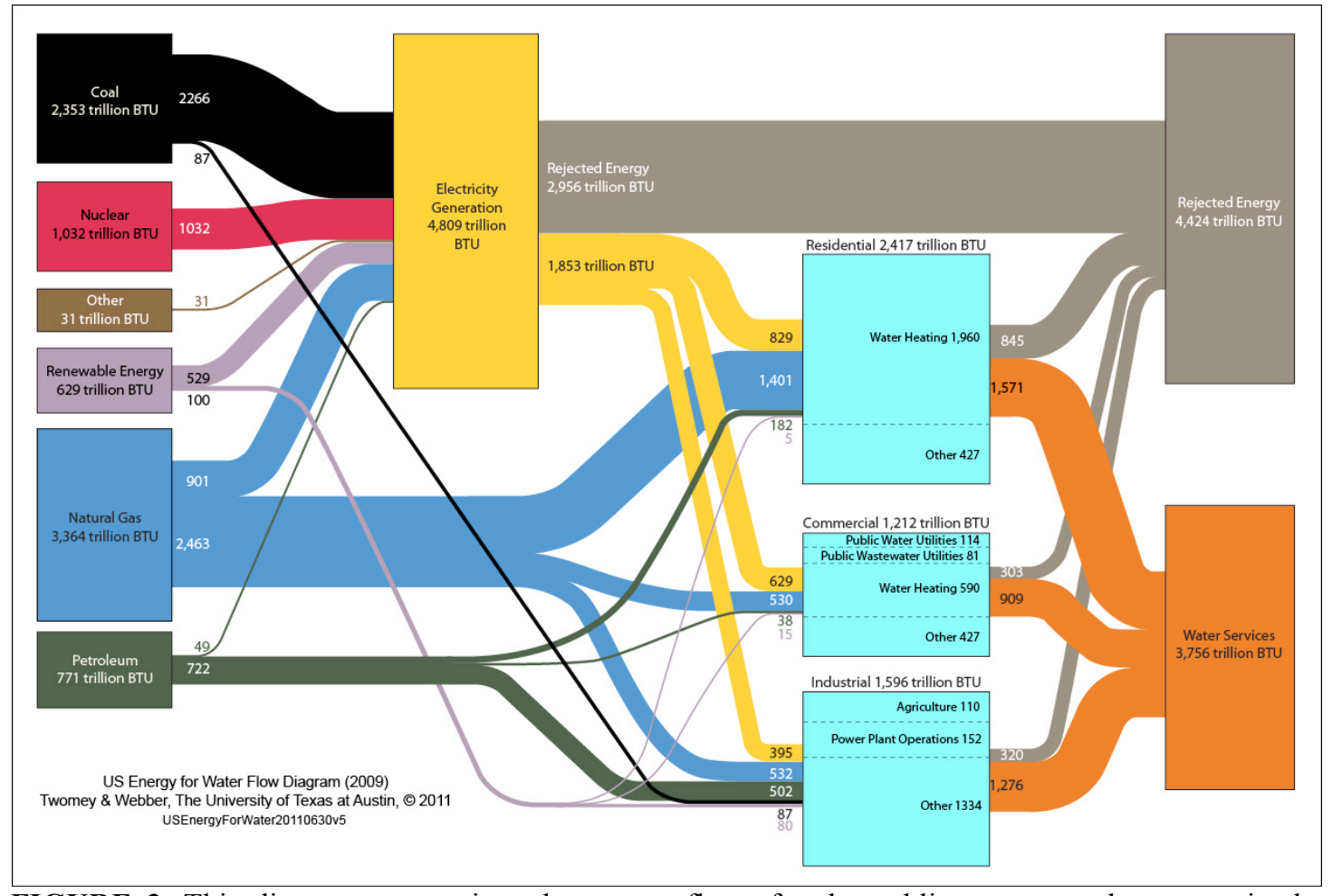

FIGURE 3. This diagram summarizes the energy flows for the public water supply system in the United States. Fuels (on the left) are used directly and indirectly via electricity generation for different purposes (on the right). The thickness of the flows is proportional to the amount of energy consumed. About $60 \%$ of the total energy consumption is lost as waste heat. Only energy consumption related to the conveyance, treatment, distribution and heating (in the commercial and residential sectors) and public water and wastewater treatment distributed in the US public water supply is included. Selfsupplied sectors, including agriculture and industry are not included.[80]

While water limitations can restrict energy, energy limitations can also restrict water. For example, power outages (due to storms or intentional acts) at water and wastewater treatment plants puts the water system at risk of disruptions due to energy shortages. And, this tradeoff becomes a strategic question for some countries. Saudi Arabia uses a lot of its own best products - crude oil and natural gas - to get what it doesn't have-freshwater-facing the choice about whether it's better to sell the energy resources at record prices or have enough freshwater available to maintain municipal needs.[59, 60]

\section{TRENDS IMPLY STRAIN IN THE ENERGY \& WATER RELATIONSHIP WILL BE EXACERBATED}

While there is already strain in the energy-water relationship, trends imply that this strain will be exacerbated because of:

1) Growth in total demand for energy and water, primarily driven by population growth, 
2) Growth in per capita demand for energy and water, primarily driven by economic growth,

3) Global climate change, which will distort the availability of water, and

4) Policy choices, by which we are selecting more water-intensive energy and more energy-intensive water.

These different trends are each discussed below.

\section{Trends Imply Growth In Total Demand for Energy \& Water}

Though the global fuel mix is quite diverse in total, fossil fuels (oil, coal and natural gas) satisfy more than $80 \%$ of the world's needs for primary energy resources.[38] Total energy consumption, including traditional biomass such as wood and dung, was approximately 500 quads in 2008.[38, 39] Estimates for fossil fuel resources suggest that they should last for at least a century more, with some estimates indicating that the total resource base can last for a few centuries. The total resource of water in the world, while quite vast, is primarily undrinkable, with $97.5 \%$ in the form of saltwater.[40] Of the freshwater resources, more than two-thirds is held in ice and permanent snow cover, with most of the rest in groundwater (e.g. underground aquifers), leaving very little that is easily accessible at the surface.[40] Surface water is also mostly renewable from rainfall, though groundwater resources are often finite and slowly replenished. Total water withdrawals and consumption in 2000 were approximately 1.05 and 0.52 quadrillion gallons, respectively.[41]

\section{USA 2008 Energy Consumption: World 2008 Energy Consumption: 100 Quads 500 Quads}
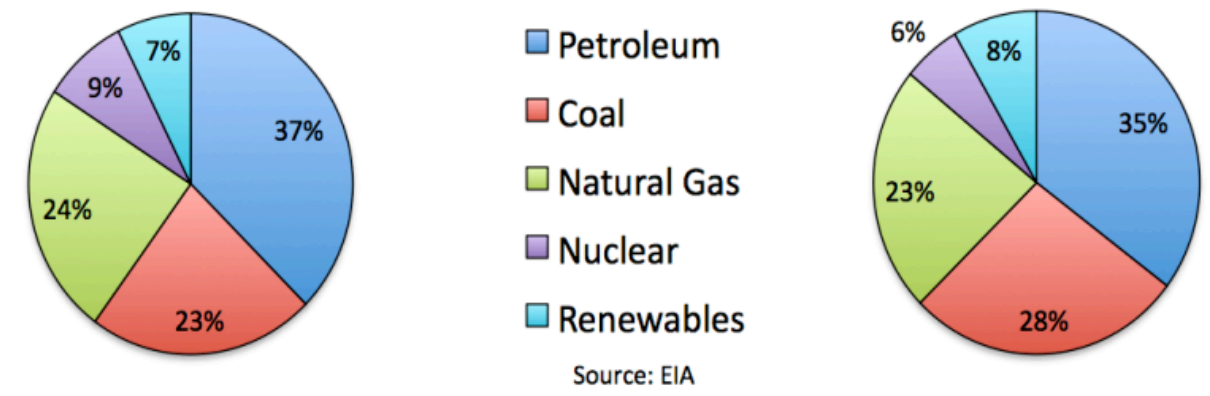

FIGURE 4. The global energy mix is diverse, though fossil fuels satisfy more than $80 \%$ of the world's primary energy resources. ${ }^{38}$ 
TABLE 4. Global water resources are primarily comprised of saltwater $(97.5 \%)$. Of the $2.5 \%$ of the world's water resources that are freshwater, more than two-thirds is in ice or permanent snow cover, with most of the remainder underground (see the bottom part of this table). Relatively little water is easily accessible on the surface. (Table constructed from Figure 2.1 in [40]).

\begin{tabular}{|c|r|}
\hline Global Water Resources & Percentage \\
\hline Saltwater & $97.5 \%$ \\
\hline Freshwater & $2.5 \%$ \\
\hline Global Freshwater Resources & Percentage \\
\hline Permafrost & $0.07 \%$ \\
\hline Rivers, lakes, and swamps & $0.34 \%$ \\
\hline Groundwater & $30.7 \%$ \\
\hline Ice and permanent snow cover & $68.7 \%$ \\
\hline
\end{tabular}

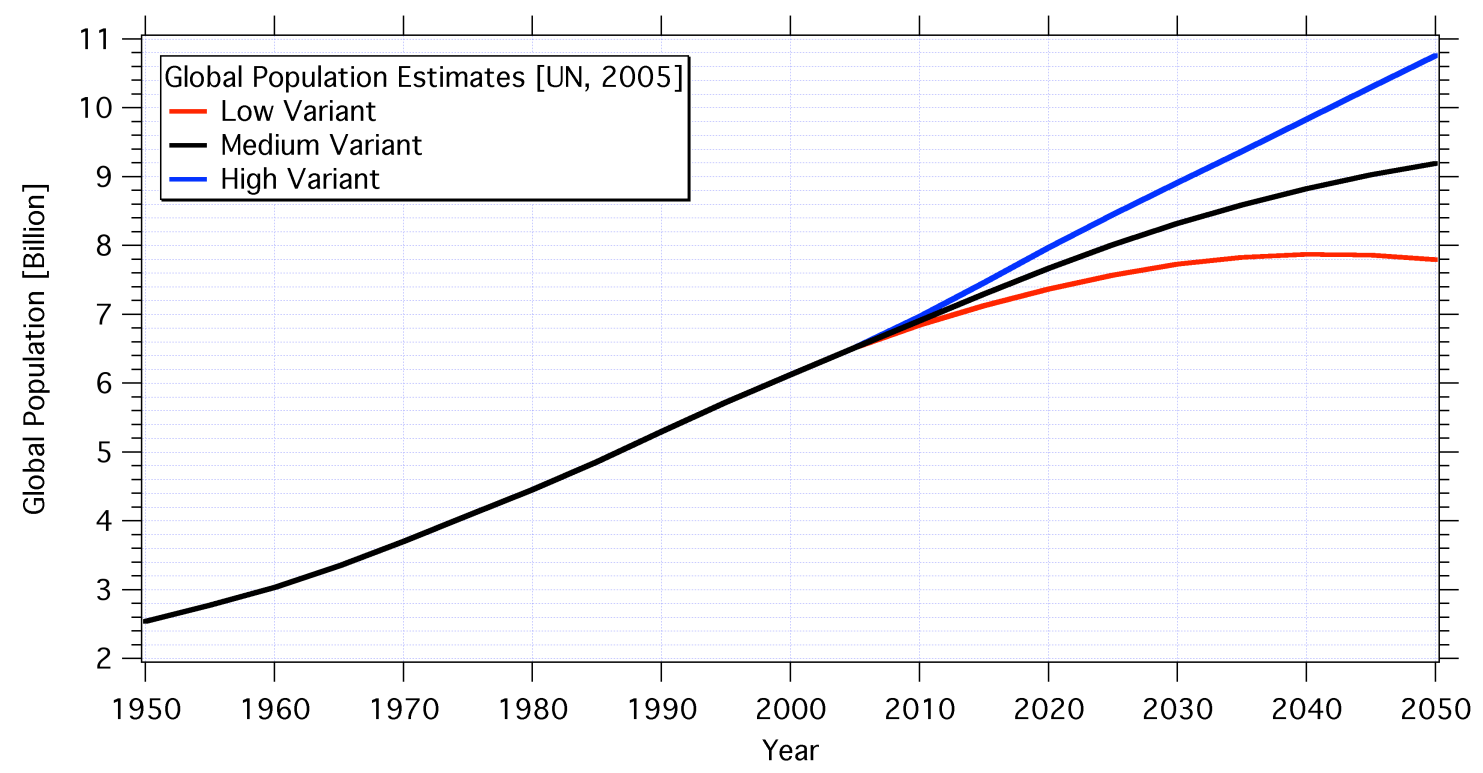

FIGURE 5. Global population projections by the United Nations show growth out to at least 2040 for low-, medium-, and high-growth variants.[42, 43]

Most projections show an increase in demand for energy, predominantly driven by both population (see Figure 5) and economic growth. The United Nations (UN) makes several projections for global population (with low-, medium- and high-growth variants), all showing population growth out to at least 2050, at which time population could potentially decrease.[42, 43] The International Energy Agency (IEA), assumes for its projections that 1) global population will grow 1\% per year on average from 6.4 billion in 2004 to 8.1 billion in 2030, and 2) that economic growth will take place at an average of 3.4\% per year over the same period.[39] The IEA interprets these growth 
trends to yield a growth in global primary energy demand of $70 \%$ between 2004 and 2030, without a very significant shift in the basic makeup in the fuel mix, despite recent policy prioritization for biofuels and other renewable sources.[39] Similarly, this population growth should lead to increases in global water demand.[12]

\section{Trends Imply Growth In Per Capita Demand for Energy \& Water}

As the world population grows, the global demand for energy and water are increasing in order to meet the subsistence and lifestyle needs for its inhabitants. On top of this fundamental upward trend in demand is a more alarming trend: the per capita demand for energy and water are also growing. Even though the developed world is looking for ways to conserve energy and water, the developing world is in a phase of rapidly accumulating wealth. One consequence of this affluence is a desire for better transportation, a nicer lifestyle, more meat-intensive diets, and a robust economy. The combined effect is that the demand in developing countries is increasing rapidly for liquid fuels, electricity, and water (for industrial processes, higher-protein diets, and pretty yards and gardens). This statistic means the growth in demand for energy and water is outpacing the growth in population. For a world that already has these resources under strain, accelerating demand might have far-reaching impacts.

Despite population growth estimates of only 19 to 37\% [42, 43] from 2004-2030, as noted before, the IEA projects energy demand increases that are much greater, at approximately 70\% [39], indicating that annual per capita energy use globally will increase from roughly 1.7 to 2.1 tons of oil equivalent. About half of the growth in demand is projected to be from the power sector [39], revealing that electricity is a preferred form of energy for those who can afford it. Because of the power sector's water intensity, the new demand for electricity will likely lead to increased demand for water withdrawals as well. In its projections, the IEA's World Energy Outlook 2006 also considers an alternative policy scenario, for which energy growth is lower than the nominal reference projection for energy growth. Even for this alternative case, both the absolute and per-capita energy demand are expected to increase between 2004 and 2030.[39] Even in the United States, where energy-intensive manufacturing has shrunk relatively, the per capita energy use is projected to increase by the EIA.[17]

One of the drivers of increasing energy use per capita is the expectation that people demand better environmental conditions as their incomes rise (that is, they move along the downward-sloping part of the environmental Kuznets curve).[44] This phenomenon is illustrated here for the case of wastewater treatment. The EIA projected in 2006 that the US population would increase about 70 million over the next 25 years, generating a commensurate increase in the amount of wastewater that will need to be treated and POTWs energy use.[32] A US Environmental Protection Agency (EPA) study published in 2002 found that capital needs (collection, pumping and treatment facilities) for wastewater over a twenty year period from $2000-2019$ would range from $\$ 331$ billion to $\$ 440$ billion.[45] Increasingly, POTWs' discharge permits require the removal of specific contaminants (such as nitrogen) not removed by conventional treatment technologies, thus requiring the installation of advanced wastewater treatment technologies.[46] Additionally, concerns about chlorine 
disinfection byproducts are forcing many POTWs to install new disinfection technology.[47] Advanced wastewater treatment is generally more energy intensive than standard wastewater treatment and so the trend towards these higher treatment standards will likely increase the unit energy needs of wastewater treatment in the future.[47] Because of the growing US population, stricter discharge requirements and aging wastewater infrastructure, the Energy Policy Research Institute (EPRI) projects that national POTWs energy use will increase in the future.[47] However, according to the EIA, it is possible that the introduction of greater energy efficiency at POTWs will offset the expected increases in energy intensity for stricter treatment standards, limiting the projected growth in electricity use at POTWs to approximately 15 percent from 2005 to 2030 , which is less that what would have been expected for the nominal $0.8 \%$ average annual population growth.[17] The higher per capita energy expenditures for wastewater treatment in order to achieve stricter environmental standards is a scenario likely to be repeated in analogous ways throughout all the societies that are achieving affluence; that is, as nations get richer, they will demand more energy.

While the per capita energy demand is clearly on an upward trend, the situation with water is less clear. At the same time that human population has tripled in the last seventy years, water withdrawals have increased six-fold.[40, 48] Water withdrawals might have increased by a factor of forty in the last three centuries.[40, 49] Furthermore, in the present-day situation, high-income countries have annual per capita freshwater withdrawals in excess of 600 cubic meters, while low-income countries have annual per capita withdrawals of less than half with less than 300 cubic meters and middle-income countries have withdrawals rates that are in between the two.[40] As middle- and low-income countries become wealthier, it is reasonable to expect that their per capita withdrawals will rise to match those of high-income countries, driving up the global per capita freshwater withdrawals. One driving force for increased per capita withdrawals is the expectation that along with economic growth will come growth in meat consumption, which will increase the water demand for fodder production.[12]

It is important to note that not all projections show increasing per capita water withdrawals. For example, water use estimates from a joint project in 1999 between UNESCO and the State Hydrological Institute in St. Petersburg yields a possible global peak in per capita water withdrawals and consumption near 1980, if that water use is normalized by UN population estimates.[41, 42, 50]. However, because those estimates are at low temporal resolution and are not updated with data that include the recent effects of globalization, it is difficult to project their forward-looking implications with much confidence. 


\section{Global Climate Change and Trends Will Intensify This Strain}

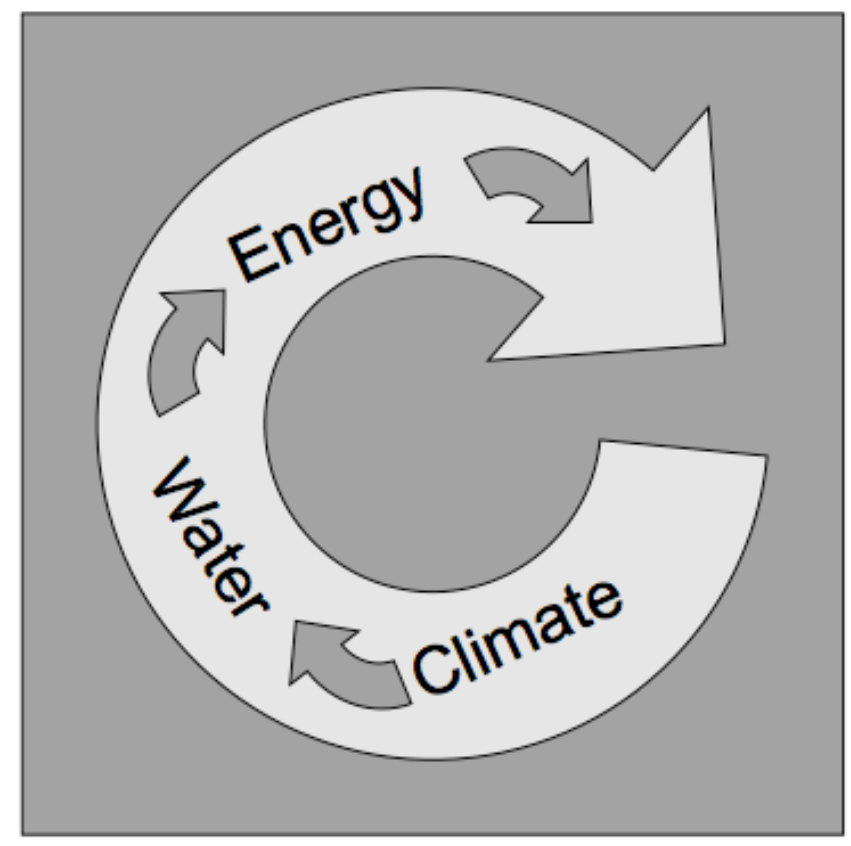

FIGURE 6. The energy-climate-water cycle creates a self-reinforcing challenge. (Image based on suggestion of Jane Long at Lawrence Livermore National Laboratory.)

One important aspect of climate change is that the water systems are likely to be hit hardest and will be a leading indicator of temperature changes. Popular discussion of climate effects often focuses on the risks of rising sea levels, but it is the risk of changes to the hydrological cycles that might be of greater concern. These effects are hard to predict, but it is expected that higher temperatures could induce several consequences, including turning some snowfall into rainfall, moving the snowmelt season earlier (and thereby affected spring water flows), increasing intermittency and intensity of precipitation, affecting water quality and raising the risks of floods and droughts.[12, 61] In addition, the sea level rises can cause contamination of groundwater aquifers with saline water near the coasts, potentially affecting nearly half of the world's population.[12] These challenges can be fixed with greater energy expenditures for mining deeper water, moving it farther, treating water to make it drinkable, or storing it for longer periods of time. With a typical energy mix over the next few decades, these energy expenditures release greenhouse gases, which intensify the hydrological cycle further, compounding the problem in a positive feedback loop (see Figure 4). 


\section{POLICY CHOICES ARE MOVING TOWARDS MORE ENERGY- INTENSIVE WATER AND MORE WATER-INTENSIVE ENERGY}

On top of the prior three trends is a policy-driven movement towards more energyintensive water and water-intensive energy.

\section{Trends Imply Growing Energy-Intensity of Water}

All the aforementioned trends also indicate a movement towards water-production methods that are increasingly energy-intensive. We are moving towards more energyintensive water because of a push by many municipalities for new supplies of water from sources that are farther away and lower quality, and thereby require more energy to get them to the right quality and location.

Because of growing environmental concerns, our standards for water treatment get stricter with time, as we expect our water to be ever cleaner, and so the amount of energy we spend per gallon will only increase. And, like water, the treatment standards are getting stricter with time as we wish to treat the wastewater to a higher degree of cleanliness. Prior analysis projects that unit electricity consumption for water treatment has increased at a compound rate of $0.8 \%$ per year, with no obvious reason why the trend would stop.[47] In the US, aging wastewater infrastructure will also tend to increase unit electricity use due to age-related losses while other factors (for example, replacing older equipment with more efficient new equipment and processes and larger treatment plants with higher energy economies of scale) will tend to decrease unit energy consumption, but not enough to offset the energy needs of higher level treatment.[47]

In addition to treating water to higher standards of cleanliness, societies are also going to greater lengths to bring freshwater from its sources to dense urban areas. These efforts include digging to ever-deeper underground reservoirs, or by moving water via massive long-haul projects.[79] For example, China is implementing a gargantuan water transport plan named the "South-North Water Transfer Scheme", which is an order of magnitude larger than California's famed aqueduct and will move water from three river basins in the wet southern part of China to the dry northern parts.[13] Two of these routes are more than $1000 \mathrm{~km}$ long,[13] therefore representing substantial investments in energy for transport. Similar efforts are happening in Texas, where private investors are proposing a project to move groundwater from the Ogallala Aquifer (one of the world's largest) in the panhandle hundreds of miles across the state of Texas to the thirsty municipalities in the Dallas/Fort Worth metroplex.[62]

On April 12, 1961, President Kennedy said, "If we could ever competitively - at a cheap rate - get fresh water from salt water that would be in the long-range interest of humanity, and would really dwarf any other scientific accomplishment.'[63] A few months later, he signed a bill to set the US on a research course to seek a breakthrough in desalination.[64] Since that time, global desalination capacity has enjoyed a decades-long steep upward trend.[65, 66] It's unlikely this trend will end soon given the other trends noted above. While desalination is traditionally associated with the Middle East, where energy resources are plentiful but water is scarce, cities like El 
Paso and San Diego are trying to develop desalination plants to get fresh water either from their nearby saline aquifers or coasts. California alone has approximately twenty seawater desalination plants that are proposed.[66] The steep market penetration rates for desalination are particularly relevant for the adoption of new membrane-based technologies.[66, 67] While these membrane-based reverse-osmosis approaches are less energy-intensive than thermal desalination, they still require much more energy than traditional freshwater production from surface sources.

\section{Trends Imply Growing Water-intensity of Energy}

At the same time, for a variety of economic, security and environmental reasons, including the desire to produce a higher proportion of our energy from domestic sources and to decarbonize our energy system, many of our preferred energy choices are more water-intensive. For example, nuclear energy is produced domestically, but is also more water-intensive than other forms of power generation. The move towards more water-intensive energy is especially relevant for transportation fuels such as unconventional fossil fuels (oil shale, coal-to-liquids, gas-to-liquids, tar sands), electricity, hydrogen, and biofuels, all of which can require significantly more water to produce than gasoline (depending on how you produce them). It is important to note that the push for renewable electricity also includes solar photovoltaics (PV) and wind power, which require very little water, and so not all future energy choices are worse from a water-perspective.

Almost all unconventional fossil fuels are more water-intensive than domestic, conventional gasoline production. While gasoline might require a few gallons of water for every gallon of fuel that is produced, the unconventional fossil sources are typically a few times more water-intensive. Electricity for plug-in hybrid electric vehicles (PHEVs) or electric vehicles (EVs) are appealing because they are clean at the vehicle's end-use and it's easier to scrub emissions at hundreds of smokestacks millions of tailpipes. However, most powerplants use a lot of cooling water, and consequently electricity can also be about twice as water-intensive than gasoline per mile traveled if the electricity is generated from the standard U.S. grid. If that electricity is generated from wind or other water-free sources, then it will be less water-consumptive than gasoline. Though unconventional fossil fuels and electricity are all potentially more water-intensive than conventional gasoline by a factor of 2-5, biofuels are particularly water-intensive. Growing biofuels consumes approximately 1000 gallons of water for every gallon of fuel that is produced. Sometimes this water is provided naturally from rainfall. However, for a non-trivial and growing proportion of our biofuels production, that water is provided by irrigation.

Today's sustained higher energy prices and emerging political consensus about climate change and energy security have brought fossil fuels into new scrutiny. Consequently, the US in particular is seeking an energy solution that is domestically sourced (addressing some of the national security concerns), abundant (addressing the concerns about resource depletion), and less carbon-intensive (addressing our concerns about climate change). Because the amount of oil imported by the US is approximately the same as what is needed by the transportation sector,[17] and 
because this sector is a major contributor to carbon emissions, it is on the short-list of targets for change by policymakers, innovators, and entrepreneurs.

Among the options are unconventional fossil fuels (including compressed natural gas, coal-to-liquids, tar sands and oil shale), hydrogen, biofuels and electricity. While these options have their merits, most production methods for these options are more water-intensive than conventional petroleum-based gasoline and diesel (please see Figure 5 or the recent publication by King \& Webber for more details). [68] Oil shale and tar sands both are very water-intensive for their production. For example, in-situ oil shale production might use vast amounts of electric power to heat the bitumen underground; that electric power will likely need water cooling. Tar sands are produced through the use of steam injection to reduce the viscosity of the tars. While coal production is not particularly water-intensive, creating liquid fuels from coal using Fischer-Tropsch processes requires water as a process material. Hydrogen can also be very water-intensive if produced via electrolysis.[20] However, if hydrogen is produced from non-irrigated biomass resources or via reforming of fossil fuels, its water-intensity is on par with conventional gasoline production and use.

Electricity is particularly appealing as a transportation fuel for a variety of reasons. By running light-duty vehicles on electricity, it is possible to shift a significant portion of our transportation system away from imported oil to mostly domestic fuels, namely coal, gas, nuclear, wind, solar, and hydroelectric power. Moreover, from an environmental mitigation standpoint, it's easier to manage the emissions from 1500 power plants than from hundreds of millions of tailpipes. It is also convenient that the electrical infrastructure and capacity are already in place. However, as noted before, the power sector is very water intensive, and creating more demand for electricity will only exacerbate those effects.

Biofuels are also very popular because they are grown domestically and they consume $\mathrm{CO}_{2}$ during photosynthesis. They also hold the potential for displacing fossil fuels, though many have suggested that first generation biofuels (e.g. corn-based ethanol) provide about as much energy as they require for their growth.[69] The real challenge for biofuels is their water intensity, though there are also some important water quality impacts.[81] Recent analysis indicates that irrigated biofuels can require over one hundred gallons of water for every mile traveled in a light-duty vehicle [68, 70], approximately one thousand times more water per mile than conventional gasoline. When scaling up this kind of production to prepare for approximately 140 billion gallons per year of gasoline equivalent energy and trillions of miles traveled, water can become a critical limiting factor. In fact, some municipalities are already in a fight over water resources with the biofuels industry,[71] which might only grow as the industry expands to meet governmental mandates. 


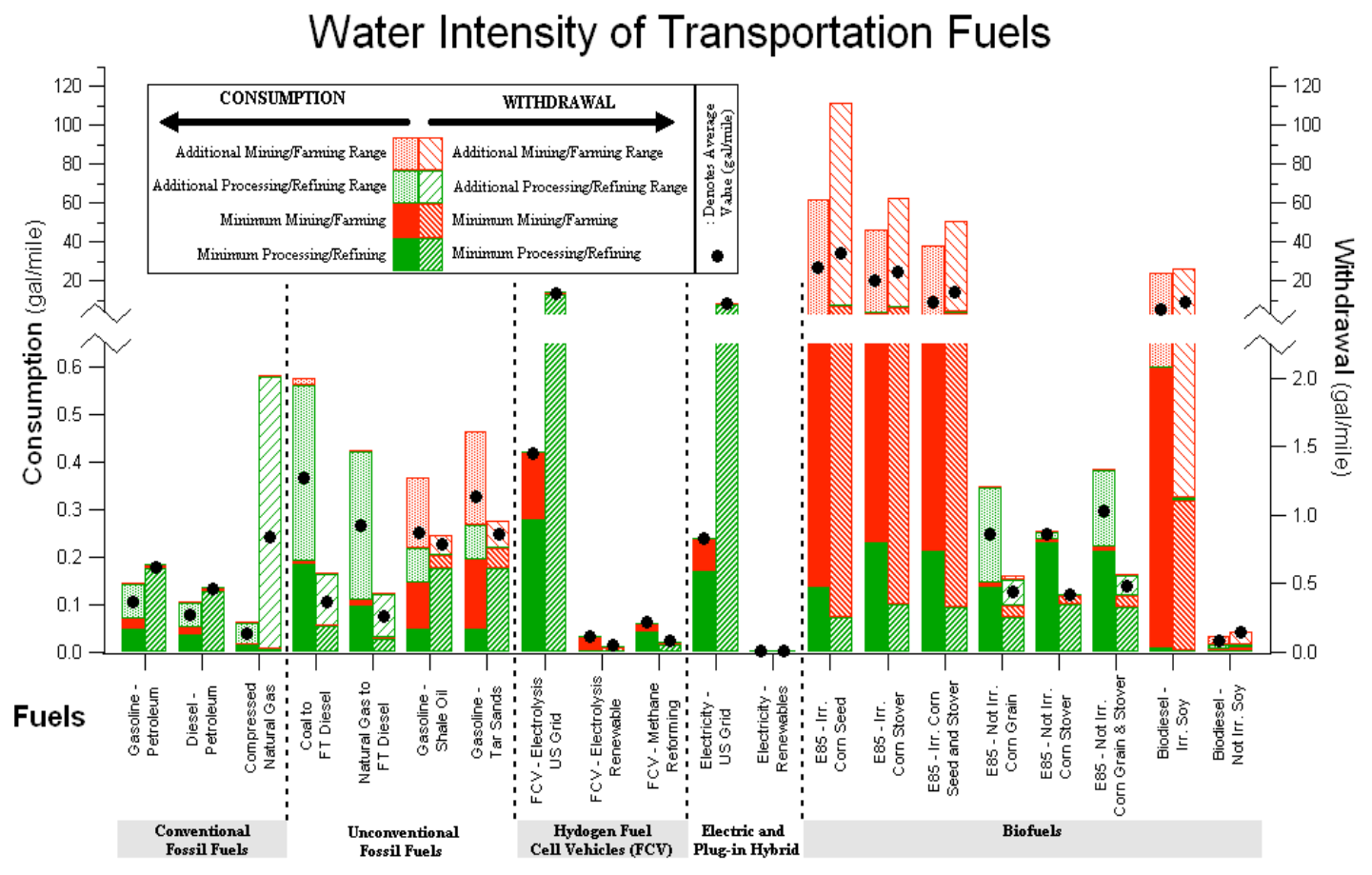

FIGURE 7. The water-intensity of different fuels in gallons of water require per mile traveled, show great variation from irrigated biofuels (at the high end, withdrawing and consuming more than 20 gallons of water per mile) to electricity from wind or solar resources (at the low end, requiring approximately 0 gallons of water per mile). Water consumption (left stacked bars read on left axis) and withdrawal (right stacked bars read on right axis) in gallons of water per mile (gal $/ \mathrm{mile}$ ) for various fuels for light duty vehicles. Water use from mining and farming is designated differently from that used for processing and refining. Where a range of values exists (e.g. different irrigation amounts in different states), a minimum value is listed with an 'additional range'. Otherwise, the values plotted are considered average values. Irr. $=$ irrigated, Not Irr. $=$ not irrigated, FT $=$ Fischer Tropsch, FCV $=$ fuel cell vehicle, US Grid = electricity from average US grid mix, and Renewables = renewable electricity generated without consumption or withdrawal of water (e.g. wind and photovoltaic solar panels).[68]

Recent energy legislation in the US and "energy independence" scenarios envisioned by the US DoE incorporate a rapid shift towards these more waterintensive fuels. For example, the Energy Independence and Security Act of 2007 (EISA 2007) includes requirements for corporate average fuel economy (CAFE) improvements and increased renewable fuel use.[72] These renewable fuels include irrigated biofuels such as corn-based ethanol. For example, the EISA 2007 mandates the production of biofuels increases to 36 billion gallons per year (Bgal/yr) by 2022, of which up to $15 \mathrm{Bgal} / \mathrm{yr}$ can be ethanol from corn grain.[72] A recent study by King, et al [74], calculated the water consumption and withdrawal that would result from the implementation of EISA 2007.[73] King's study considered light duty vehicle (LDV) travel (in 2005 LDV travel totaled 2.7 trillion miles driven by cars, pickup trucks, vans, and SUVs), and used those two projections of future fuel usage and previously published calculations of water usage rates in gallons per mile $\left(\mathrm{gal} \mathrm{H}_{2} \mathrm{O}\right.$ /mile) driven using various fuels.[68] Converting projected fuel usage (units of fuel) into miles driven and then multiplying by water usage rates per mile yielded an estimate for the 
total water to be consumed and withdrawn for driving LDVs looking forward out to 2030. This analysis shows a considerable increase in water consumption and withdrawal for all analyzed future fuel scenarios. In 2005 it is estimated that 1,440 and 2,800 billion gallons of water were consumed and withdrawn, respectively, for LDV travel. By 2030 it is estimated that for both cases analyzed, approximately 2,600-2,700 billion gallons of water per year, 9\% of estimated US fresh water consumption, will be consumed in the farming, mining, and refining of LDV fuels. Water withdrawal for LDVs in 2030 will be 4,700-6,500 Bgal/yr. Agricultural irrigation heavily dominates both water consumption and withdrawal accounting for $80 \%-85 \%$ and $45 \%-65 \%$ of the 2030 total for each category, respectively. Thus, increasing fuel usage, along with a higher diversity of fuels, generally causes an increase in water usage. The amount of this increase depends heavily upon which alternative fuels the US will produce, but the total effect in the US can be an additional few trillion gallons of water consumption annually.

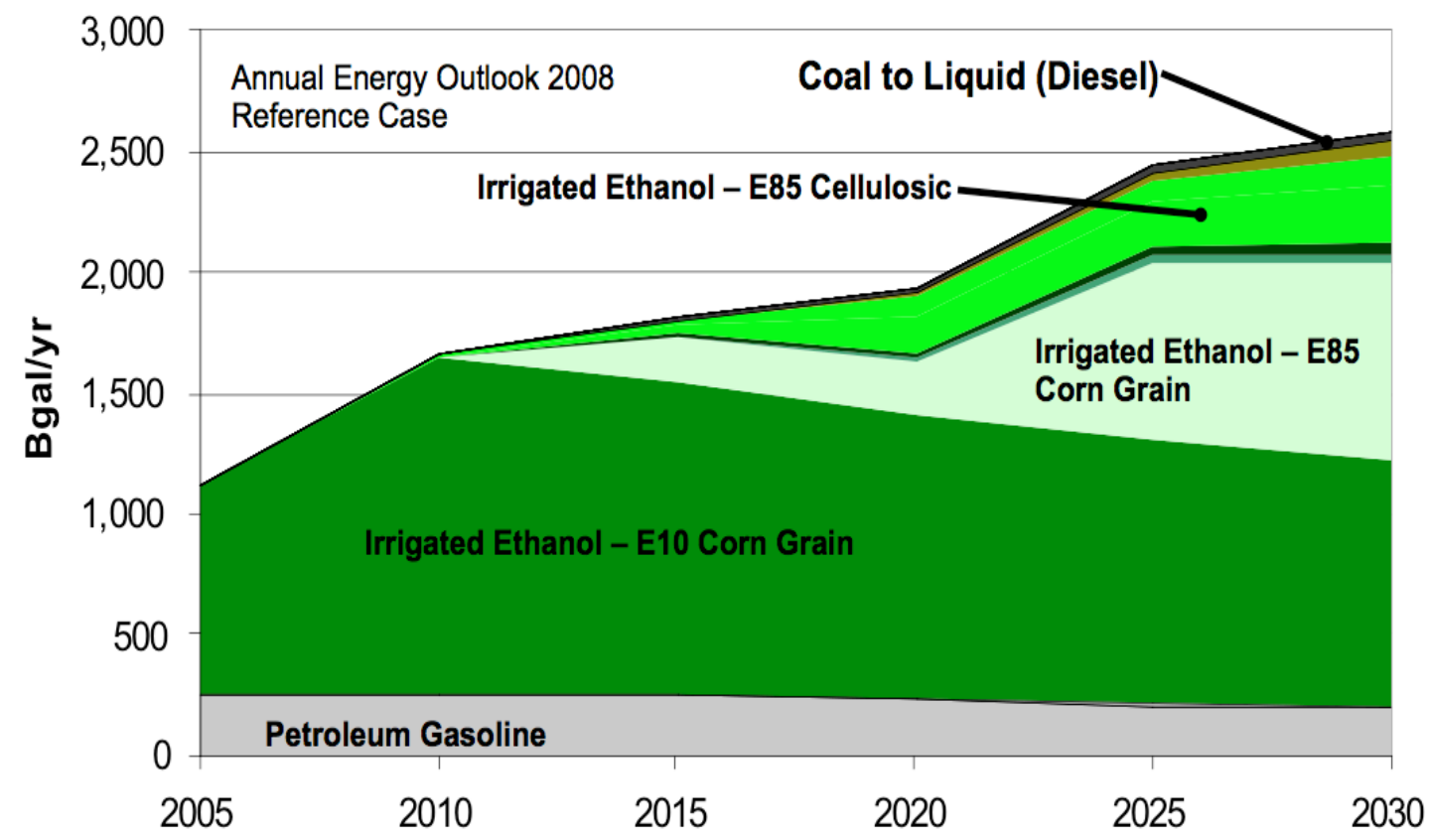

FIGURE 8. The water needs for producing transportation fuels are projected to grow dramatically (by trillions of gallons per year) primarily because of biofuels mandates.[74]

\section{CONCLUSIONS AND RECOMMENDATIONS}

The nexus of water and energy is fundamental to society, is intertwined in many ways, is under strain today, and is projected to get worse as worldwide demand for both increases more quickly than population and the effects of climate change manifest themselves. While the energy-water relationship might appear intractable, there are many opportunities to mitigate the worst aspects through new technologies, new concepts for how to reuse water effectively, new markets that put a price on water, and 
a recognition that conserving water and conserving energy are synonymous. Though the world's water situation appears dire for many reasons, it also presents an opportunity and we have many tools available to tackle the problem. And, in particular, policy engagement is warranted.

Because there are many rivers, watersheds, basins and aquifers that span several states and/or countries, there is a need for federal engagement on energy-water issues. Unfortunately, there are some policy pitfalls at the energy-water nexus. For example, energy and water policymaking are disaggregated. The funding and oversight mechanisms are separate, and there are a multitude of agencies, committees, and so forth, none of which have clear authority. It is not unusual for water planners to assume they have all the energy they need and for energy planners to assume they have the water they need. If their assumptions break down, it could cause significant problems. In addition, the hierarchy of policymaking is dissimilar. Energy policy is formulated in a top-down approach, with powerful federal energy agencies, while water policy is formulated in a bottom-up approach, with powerful local and state water agencies. Furthermore, the data on water quantity are sparse, error-prone, and inconsistent. The United States Geological Survey (USGS) budgets for collecting data on water use have been cut, meaning that their latest published surveys are anywhere from 5 to 15 years out of date. National databases of water use for power plants contain errors, possibly due to differences in the units, format and definitions between state and federal reporting requirements. For example, the definitions for water use, withdrawal and consumption are not always clear. And, water planners in the east use "gallons" and water planners in the west use "acre-feet," introducing additional risk for confusion or mistakes.

Despite the potential pitfalls, there are policy opportunities at the energy-water nexus. For example, water conservation and energy conservation are synonymous. Policies that promote water conservation also achieve energy conservation. Policies that promote energy conservation also achieve water conservation.

Thankfully, the federal government has some effective policy levers at its disposal. I recommend the following policy actions for the energy-water nexus:

1. Collect, maintain and make available accurate, updated and comprehensive water data, possibly through the USGS and EIA. One of the challenges of researching this nexus is the lack of suitable water data that are available. The Department of Energy's Energy Information Administration maintains an extensive database of accurate, up-to-date and comprehensive information on energy production, consumption, trade, and price available with temporal and geographic resolution and standardized units. Unfortunately, there is no equivalent set of data for water. In fact, the National Academy of Sciences complained explicitly that water data and monitoring budgets have been cut.[67] Resuming prior national efforts to collect relevant water data and broaden the scope of monitoring capabilities will enable thoughtful analysis and will illuminate key insights into this problem, after which policymakers can respond. Without good data about water reserves, flows and use, it will be difficult for analysts to assess the situation and for policymakers to respond, and this hurdle remains one of top barriers to effective action. 
2. Invest heavily in water-related $R \& D$ to match recent increases in energyrelated $R \& D$. $R \& D$ investments are an excellent policy option for the federal government because state/local governments and industry usually are not in a position to adequately invest in research. Consequently, the amount of R\&D in the water sector is much lower than for other sectors such as pharmaceuticals, technology, or energy. Furthermore, since energy-related R\&D is expected to go through a surge in funding, it would be appropriate from the perspective of the energy-water nexus to raise water-related R\&D in a commensurate way. Topics for R\&D include low-energy water treatment, novel approaches to desalination, remote leak detectors for water infrastructure, and air-cooling systems for power plants. In addition, DoE's R\&D program for biofuels should emphasize feedstocks such as cellulosic sources or algae that do note require freshwater irrigation.

3. Develop regional water plans that consider increased demands for electricity, and regional energy plans that consider increased demands for water. For example, the rise of biofuels or electricity as fuel substitutes will have very different regional impacts. Biofuels will affect water use in the farm belt, whereas electric vehicles will affect water use at power plants near major population centers.

4. Encourage resource substitution to fuels that have water, emissions and security benefits. Some fuel sources such as natural gas, wind, and solar PV are domestic, need much less water, and reduce emissions of pollutants and carbon.

5. Support the use of reclaimed water for irrigation and process cooling. Using reclaimed water for powerplants, industry, and agriculture can spare a significant amount of energy and cost. However there are financing, regulatory and permitting hurdles in place that restrict this option. Reuse water can also reduce the demand for freshwater, for example by using reclaimed water (e.g. treated wastewater) for power plant cooling or other industrial uses along with irrigation. There is precedent for such action, as "nearly $80 \%$ of water used in the industrial sector in Japan is currently recycled.'[12] While most cities would refrain from using treated wastewater as a source of drinking water, this avenue is also available and has been implemented in water-scarce Singapore and the International Space Station without ill-effects. Consequently, it is recommended that municipalities affected by water-scarcity should move aggressively towards the use of reclaimed water.

6. Support the use of dry and hybrid wet-dry cooling at powerplants. Not all powerplants need wet cooling all the time. Finding ways to help plants upgrade their cooling to less water-intensive versions can spare significant volumes of water to meet public supply or in-stream flow requirements. 
7. Establish strict standards in building codes for water efficiency. Building codes should include revised standards for low-flow appliances, water-heating efficiency, purple-piping for reclaimed water, rain barrels and so forth in order to reduce both water and energy consumption.

8. Invest aggressively in conservation. Water conservation can be a costeffective way to save energy, and energy conservation can be a cost-effective way to save water. Therefore, conservation has cross-cutting benefits.

Conservation is one of the easiest and most cost-effective approaches to reducing both water and energy use, especially since saving water is synonymous with saving energy, and vice-versa.[28, 77] While conservation will not solve all of our energy and water problems nationally, it will buy us some time while new solutions are developed.

\section{ACKNOWLEDGMENTS}

This chapter was written based on a lecture that the author first gave in 2006, and which has evolved dramatically over the years based on the extensive research contributions from a variety of people, especially Dr. Carey King, Mrs. Ashlynn Stillwell, Ms. Kelly Twomey, Dr. Ian Duncan, Ms. Amy Hardberger and Mr. David Hoppock. The author would like to acknowledge them for their significant contributions to this body of work, including prior publications and facts and figures that were incorporated into this manuscript. The research was supported by the Center for International Energy and Environmental Policy at the University of Texas.

\section{REFERENCES}

1. National Geographic, 1993, 184.

2. National Geographic, 1981.

3. Nature, 2008, 452, 253-386.

4. Science, $2007,315,721-896$.

5. Science, 2006, 313, 1005-1184.

6. M. Hightower and S. A. Pierce, Nature, 2008, 452.

7. C. W. King, A. S. Holman and M. E. Webber, Nature Geoscience, 2008, 1.

8. H. Fountain, in New York Times, New York, NY, Edition edn., 2008.

9. A. Price, in Austin American-Statesman, Austin, Texas, Edition edn., 2008.

10. Subcommittee on Energy and Environment, Committee on Science and Technology, US House of Representatives, and Committee on Energy and Natural Resources, US Senate, Washington, DC, 2007.

11. Water for Life ISBN 924156293 5, World Health Organization, 2005.

12. T. Oki and S. Kanae, Science, 2006, 313, 1067-1072.

13. R. Stone and H. Jia, Science, 2006, 313, 1034-1037.

14. D. Kennedy and B. Hanson, Science, 2006, 313.

15. R. P. Schwarzenbach, B. I. Escher, K. Fenner, T. B. Hofstetter, C. A. Johnson, U. v. Gunten and B. Wehrli, Science, 2006, 313, 1072-1077.

16. A. Fenwick, Science, 2006, 313, 1077-1081.

17. USDOE, Annual Energy Outlook 2007: With Projections to 2030, U.S. Department of Energy, Energy Information Administration, 2007. 
18. Lake Mead Could Be Dry by 2021, http://scrippsnews.ucsd.edu/Releases/?releaseID=876.

19. S. S. Hutson, N. L. Barber, J. F. Kenny, K. S. Linsey, D. S. Lumia and M. A. Maupin, Estimated Use of Water in the United States in 2000, U.S. Geological Survey, Reston, VA, 2004.

20. M. E. Webber, Environmental Research Letters, 2007, $2,7$.

21. P. Torcellini, N. Long and R. Judkoff, Consumptive Water Use for U.S. Power Production NREL/TP-55033905, National Renewable Energy Laboratory, U.S. Department of Energy, Golden, CO, 2003.

22. Comparison of Alternate Cooling Technologies for California Power Plants: Economic, Environmental and Other Tradeoffs, California Energy Commission, 2002.

23. in The Associated Press, Editon edn., January 23, 2008.

24. M. Poumadère, C. Mays, S. L. Mer and R. Blong, Risk Analysis, 2005, 25, 1483-1494.

25. P. Lagadec, Journal of Contingencies and Crisis Management, 2004, 12, 160-169.

26. Water \& Sustainability (Volume 3): U.S. Water Consumption for Power Production - The Next Half Century, Electric Power Research Institute, 2002.

27. California's Water-Energy Relationship: Final Staff Report, California Energy Commission, 2005.

28. R. Cohen, B. Nelson and G. Wolff, Energy Down the Drain: The Hidden Costs of California's Water Supply, Natural Resources Defense Council, 2004.

29. USDOE, End-Use Consumption of Electricity 2001, U.S. Department of Energy, Energy Information Administration, 2001.

30. A.S. Stillwell, D.C. Hoppock and M.E. Webber, "Energy Recovery from Wastewater Treatment Plants in the United States: A Case Study of the Energy-Water Nexus," Sustainability (special issue Energy Policy and Sustainability) 2010, 2(4), 945-962.

31. Water \& Sustainability (Volume 4): U.S. Electricity Consumption for Water Supply \& Treatment - The Next Half Century, Electric Power Research Institute, 2002.

32. USDOE, Energy Demands on Water Resources: Report to Congress on the Interdependency of Energy and Water, United States Department of Energy, 2006.

33. M. S. Shannon, P. W. Bohn, M. Elimelech, J. G. Georgiadis, B. J. Marinas and A. M. Mayes, Nature, 2008, 452, 301-310.

34. U.S. Environmental Protection Agency Office of Wastewater Management, Primer for Municipal Wastewater Treatment Systems EPA 832-R-04-001, U.S. Environmental Protection Agency, Washington D.C., 2004.

35. Water Environment Federation, Energy Conservation in Wastewater Treatment Facilities Manual of Practice, Water Environment Federation, Alexandria, VA., 1997.

36. U.S. Wastewater Treatment Factsheet, http://css.snre.umich.edu/facts/factsheets.html, Accessed March 9, 2008 , 2008.

37. R. B. Seiger and D. Whitlock, CHP and Bioenergy for Landfills and Wastewater Treatment Plants, Salt Lake City, UT, 2005.

38. J. Goldemberg, Science, 2007, 315.

39. IEA, World Energy Outlook 2010, International Energy Agency, 2010.

40. J. Boberg, Liquid Assets: How Demographic Changes and Water Management Policies Affect Freshwater Resources, RAND Corporation, Santa Monica, CA, 2005.

41. I. Shiklomanov, World Water Resources and Their use, United Nations Educational Scientific and Cultural Organization and State Hydrological Institute (St. Petersburg), 1999.

42. UN, World Population Prospects: The 2006 Revision, Population Division of the Department of Economic and Social Affairs of the United Nations Secretariat, 2006.

43. UN, World Urbanization Prospects: The 2005 Revision, Population Division of the Department of Economic and Social Affairs of the United Nations Secretariat, 2005.

44. S. Dasgupta, B. laplante, H. Wang and D. Wheeler, Journal of Economic Perspectives, 2002, 16, 147-168.

45. U.S. Enviromental Protection Agency Office of Water, The Clean Water and Drinking Water Infrastructure Gap Analysis EPA-816-R-02-020, U.S. Enviromental Protection Agency, Washington D.C., 2002.

46. BASE Energy, Energy Baseline Study For Municipal Wastewater Treatment Plants, Pacific Gas \& Electric Company, San Francisco, CA., 2006.

47. B. Applebaum, Electric Power Research Institute (EPRI), Palo Alto, CA., 2000.

48. P. H. Gleick, ed., An Introduction to Global Fresh Water Issues, Oxford University Press, New York, 1993.

49. J. N. Abramovitz and J. A. Peterson, Imperiled Waters, Impoverished Future: The Decline of Freshwater Ecosystem, World Resource Institute, Washington, DC, 1996.

50. D. Zimmer, Evolution of Water Withdrawals and Consumption Since 2900, http://www.worldwatercouncil.org/fileadmin/wwc/Water_at_a glance/Water_withdrawals_and_consumption.p pt, Accessed June 11, 2008.

51. in Fundacion Proteger, 2008.

52. P. N. Spotts, in Christian Science Monitor, 2008.

53. D. Olinger, in Denver Post, Denver, 2008.

54. J. Gertner, in New York Times Magazine, 2007.

55. A. Avison, in The Eagle, Bryan-College Station, Texas, 2008. 
56. L. Mungin, in Atlanta Journal-Constitution, Atlanta, Georgia, 2007.

57. K. Kranhold, in The Wall Street Journal, New York, New York, 2008.

58. in $B B C$, London, England, 2008.

59. USDOE, Country Analysis Briefs: Saudi Arabia, U.S. Department of Energy, Energy Information Administration, 2007.

60. IEA, World Energy Outlook 2005: Fact Sheet -- Saudi Arabia, International Energy Agency, 2005.

61. P. H. Gleick, Water: The Potential Consequences of Climate Variability and Change for the Water Resources of the United States United States Geological Survey, 2000.

62. S. Berfield, in BusinessWeek, 2008.

63. P. H. Gleick, The World's Water 2000-2001: The Biennial Report on Freshwater Resources, Island Press, Washington, 2000.

64. John F. Kennedy Library and Museum, Selected Milestones in the Presidency of John F. Kennedy, http://www.jfklibrary.org/Historical+Resources/Archives/Reference+Desk/Selected+Milestones+in+the+Presid ency+of+John+F.+Kennedy.htm, Accessed June 28, 2008.

65. P. H. Gleick, H. Cooley, D. Katz, E. Lee, J. Morrison, M. Palaniappan, A. Samulon and G. H. Wolff, The World's Water 2006-2007: The Biennial Report on Freshwater Resources, Island Press, Washington, 2006.

66. in The Economist, 2008, vol. Technology Quarterly.

67. NAS, Desalination: A National Perspective 0-309-11924-3, Committee on Advancing Desalination Technology, Water Science and Technology Board, Division on Earth and Life Studies, National Academy of Sciences, Washington, DC, 2008.

68. C.W. King and M.E. Webber, "Water Intensity of Transportation," Journal of Environmental Science and Technology 42(21), pp 7866-7872 (2008).

69. A. E. Farrell, R. J. Plevin, B. T. Turner, A. D. Jones, M. O'Hare and D. M. Kammen, Science, 2006, 311, 506-508.

70. NAS, Water Implications of Biofuels Production in the United States 0-309-11360-1, Committee on Water Implications of Biofuels Production in the United States, National Research Council, National Academy of Sciences, Washington, DC, 2007.

71. J. Paul, in Journal-Advocate, Champaign, Illinois, 2006.

72. Energy Independence and Security Act of 2007, Public Law 110-140, 2007.

73. K. Kern, P. Balash and B. Schimmoller, Attaining Energy Security in Liquid Fuels Through Diverse U.S. Energy Alternatives, DOE/NETL-2007/1278, U.S. Department of Energy, National Energy Technology Laboratory, 2007.

74. C. W. King, M. E. Webber and I. J. Duncan, "The Water Needs for LDV Transportation in the United States," Energy Policy, Vol. 38 (2), pp 1157-1167 (2010).

75. USDOE, Annual Energy Outlook 2008: With Projections to 2030, U.S. Department of Energy, Energy Information Administration, 2008.

76. E. Marris, Nature, 2008, 452, 273-277.

77. A. Hardberger, From Policy to Reality: Maximizing Urban Water Conservation in Texas, Environmental Defense Fund, Austin, TX, 2008.

78. A.S. Stillwell, C. W. King, M. E. Webber, I. J. Duncan and A. Hardberger, "The Energy-Water Nexus in Texas," Ecology and Society (Special Feature: The Energy-Water Nexus: Managing the Links between Energy and Water for a Sustainable Future) 16 (1): 2 (2011).

79. A.S. Stillwell, C.W. King and M.E. Webber, "Desalination And Long-Haul Water Transfer: A Case Study Of The Energy-Water Nexus In Texas," Texas Water Journal, Volume 1, Number 1, Pages 33-41, September 2010.

80. K.M. Twomey and M.W. Webber, "Evaluating The Energy Intensity Of The Us Public Water System," Proceedings of the $5^{\text {th }}$ International Conference on Energy Sustainability, ASME, Washington, DC, 2011.

81. K.M. Twomey, A.S. Stillwell and M.E. Webber, "Nitrate Contamination as a Result of Biofuels Production and Its Unintended Energy Impacts for Treating Drinking Water," Journal of Environmental Monitoring (2010), DOI: $10.1039 / \mathrm{b} 913137 \mathrm{j}$. 